S. Afr. J. Agric. Ext.

Tselaesele, Bagwasi, Lepetu,

Vol. 46, No. 1, 2018: 92 - 105

Bahta \& Oladele.

DOI: http://dx.doi.org/10.17159/2413-3221/2018/v46n1a450 (License: CC BY 4.0)

\title{
TRAINING NEEDS ASSESSMENT FOR TRANSFORMATION OF SMALLHOLDER LIVESTOCK FARMING IN BOTSWANA
}

Tselaesele, N. M $^{18}$, Bagwasi, N. ${ }^{19}$, Lepetu, J. ${ }^{20}$, Bahta, S. ${ }^{21}, \&$ Oladele, I. O. ${ }^{22}$

Corresponding author: N. M. Tselaesele, Email: ntselaes@buan.ac.bw

\section{ABSTRACT}

The need to improve the competitiveness of smallholder livestock owners in Botswana was studied through Training Need Assessment (TNA) with the aim of strengthening the capacity of agricultural education and extension in the livestock sector. TNA was conducted in selected areas of Botswana namely, Mogobane, Boatle and Taung villages in the South-East District as well as Serowe, Bobonong, Nata and Letlhakane in the Central District of Botswana. A simple random sampling method was used to select 395 smallholder livestock farmers. Quantitative and qualitative data were collected using a questionnaire and focus group discussions respectively. Quantitative data was analysed using means (and standard deviations). The results from focus groups were based on the coding of themes that emerged from the discussions. The results show that smallholder livestock farmers were lacking knowledge and skill in some of the following topics: Farm records and accounts; artificial insemination; feeds and feeding which include nutritional diseases and range management. It is recommended that livestock marketing, which is an important component in livestock production, be integrated into all livestock extension training programmes. Furthermore, the inclusion of diagnosis of livestock diseases, vaccination and borehole maintenance is also recommended.

Keywords: Training needs, livestock, knowledge, skill.

\section{INTRODUCTION}

Botswana is endowed with livestock, namely cattle, sheep and goats. These are kept under two main production systems - commercial farming and communal/subsistence farming. The commercial farms are characterised by fenced exclusive property rights to grazing land (freehold or leasehold land tenure system). The communal grazing land are allocated as grazing rights by Land Board Authorities to individuals on tribal land. Each system has different styles of livestock management.

Livestock management practices under the commercial system (also called ranch system) is mainly business oriented where modern technologies and improved practices are adopted to improve the potential of livestock. In these farms, calving rate is high, mortality is low, and usually off-take rates are higher compared to communal type of farming. This allows farmers

\footnotetext{
18 Botswana University of Agriculture and Natural Resources (BUAN). Private Bag 0027, Gaborone. Tel: +267 71498036 (Mobile). E-mail: ntselaes@buan.ac.bw. This work was made possible by funding and support from ILRI funded Competitiveness of Smallholder Livestock Project in Botswana.

${ }^{19}$ Botswana University of Agriculture and Natural Resources.

${ }^{20}$ Director at the Centre for Inservice and Continuing Education (CICE) - BUAN

${ }^{21}$ Project Leader, Competitiveness of Smallholder Livestock Farmers in Botswana, International Livestock Research Institute (ILRI), Gaborone

22 Professor of Agricultural Extension
} 
S. Afr. J. Agric. Ext.

Vol. 46, No. 1, 2018: 92 - 105

Tselaesele, Bagwasi, Lepetu,

Bahta \& Oladele.

DOI: http://dx.doi.org/10.17159/2413-3221/2018/v46n1a450

(License: CC BY 4.0)

in this category to have an incentive to invest by financing improvements on their farms (Mahabile, Lyne \& Panin, 2005:1).

The communal livestock production systems are characterised by poor livestock management practices. These include poor adoption of modern technologies such as controlled breeding and use of improved exotic livestock breeds, timely control of diseases and supplementary feeding. This results in high mortality and low calving rates in communal areas. Nevertheless, Bahta \& Malope, (2014:1); Jefferis, (2007:4); Mmopelwa \& Seleka (2011:1) and Nkhori, (2004:6) have indicated that the traditional livestock sector holds over $80 \%$ of cattle in Botswana as well as the majority of sheep and goats (Statistics Botswana, 2014:4). Thus, livestock provide livelihood to many indigenous Batswana (Bahta, Baker, Malope \& Katjiuongua, 2015:2). It is socially and economically important for the traditional livestock sector to be strengthened in order to provide better livelihoods to the majority of the people who reside in rural areas and who are dependent on agriculture as part of their livelihood strategies.

Hendrickx \& Mbeha, (2013:6) conducted a participatory epidemiology study in Botswana and identified the following constraints among smallholder livestock farmers: feed shortage during the dry season, shortage of water for livestock watering, incidences of tick borne diseases in the research areas, no transport to the market and lack of transport for extension workers which limited technology uptake. Bahta \& Baker (2015:108) observed the apparent high costs of sanitary and phyto-sanitary compliance along the beef value-chain in Botswana. They further identified the following constraints on livestock production and marketing: high transaction costs, keeping of ageing animals and poor market information relating to quality requirements of livestock products, and a significant negative effect on profit as a result of price of livestock feeds.

Bahta et al., (2015:12) indicated that only 12\% of smallholder livestock farmers in Botswana households used controlled cattle breeding methods and as a result use cross breeds suboptimally. Many of the constraints identified in this report can be controlled by human efforts through application of appropriate technologies that improve livestock husbandry practices disseminated through effective extension training. The Ministry of Agriculture, through Integrated Support Programme for Agriculture Development (ISPAAD), has a component of providing free seeds of Lablab Purpureus as fodder crop among smallholder farmers to grow in their arable farms in order to feed their livestock. At the same time, the Livestock Management and Infrastructure Development (LIMID) programme has components of fodder processing and construction of fodder storage facilities which individuals or group of farmers can apply for at subsidized prices (Ministry of Agriculture, 2010:7).

Training needs assessment is a tool used in human resource management literature to determine and measure "...the existence of a gap between what is required of a person to perform their duties competently and what they actually know as a basis for initiating corrective measures and or remedial education [and] a method that will bridge the gap between the required performance and the actual performance" (Nischithaa \& Rao Narasimha, 2014:51). Training needs assessment is important in farmer training because it “...provide clear guidelines as to which professional skill deficiencies must be remedied and what the profile of future trainees[farmers] should be... training needs come from underdeveloped skills, insufficient knowledge or inappropriate worker attitudes..." (Ferreira \& Abbad, 2012:79). In addition, Cekada, (2010:28) indicates that training needs assessment is meant to determine whether training is a solution to the problem. In the context of this 
S. Afr. J. Agric. Ext.

Vol. 46, No. 1, 2018: 92 - 105

DOI: http://dx.doi.org/10.17159/2413-3221/2018/v46n1a450
Tselaesele, Bagwasi, Lepetu,

Bahta \& Oladele.

(License: CC BY 4.0)

report, the training needs assessment is meant to identify the gap that exists in the livestock farming systems and whether such gaps can be closed by some form of training.

Skillnets (2013:2) suggests reasons for conducting training needs assessments. It is meant to identify the existing and required competency levels of knowledge, skills and aptitudes; it determines the content of the training programme; it enables the trainers to determine the training plan; It ensures that a targeted and relevant training is conducted; it is a means of maximising use of scarce resources, and the results of a training needs assessment can be used as a monitoring and evaluation tool of the training plan. Training needs assessment gathers knowledge from respondents about their level of knowledge on the given topic and their ability or skill of applying such knowledge in real life situation (Alibaygi \& Zarafshani, 2008:683).

Training is a mode through which the results of the needs of respondents are addressed. Training involves the acquisition of knowledge which is cognitive, abstract and includes theory and concepts, as well as tacit knowledge gained as a result of the experience of performing certain tasks (Nischithaa \& Rao Narasimha, 2014:50; Winterton, Le Deist \& Stringfellow, 2005:9). It also implies the existing skills are refreshed in order to meet the expectation of the job at hand. Skills are attributed to doing or performing the right technique at the right time. It is a product of continual practice (University of Victoria, undated:1).

Livestock production is important to Botswana's economy because it caters for the majority of people living in rural areas as well as the national economy as cattle accounts for $80 \%$ of agriculture's contribution to Botswana's gross domestic product (Mahabile, 2006:2). The main problem identified in the sector is poor management (Nkhori, 2004:4). Poor management is common in communal areas where livestock management and production indicators are low compared to commercial farms. The communal lands contain over $80 \%$ of national herd of which the majority is owned by small scale livestock farmers (Cullis \& Watson, 2005:4). This continual poor management and other factors such as intermittent drought pose a threat to the national herd. Banda \& Kazembe (2008:4) identified limited production technologies, rangeland degradation, animal production (such as management practices, feeds and feeding, breeds and breeding, economics of production as well as pasture and pasture production) and animal health related training needs, as issues identified for training.

The livestock extension activities in Botswana are conducted by the Department of Animal Production and the Department of Veterinary Services which advices farmers respectively. The Department of Animal Production provide advice to farmers, especially in communal areas, regarding better livestock management practices as well as dissemination of information and new technologies. The village extension workers under the department charged with livestock extension in Botswana are called "technical assistants" and their mandate is to work with, advise and assist livestock farmers in improving their production, income and ultimately their standard of living (Oladele, Lepetu, Subair \& Obuh, 2009:310). These extension workers visit farmers and advise them about better livestock production management practices, new technologies and implement government livestock related policies with the farmers such as the current Livestock Management and Infrastructure Development (LIMID) programme.

The Department of Veterinary Services also uses the village extension workers (technical assistants) and its support staff to provide the following services to livestock farmers: 
S. Afr. J. Agric. Ext.

Vol. 46, No. 1, 2018: 92 - 105

DOI: http://dx.doi.org/10.17159/2413-3221/2018/v46n1a450

vaccinations of both routine and critical diseases, disease control fence maintenance, animal health inspection, and animal disease management and the newly introduced Livestock Identification and Trace back System (LITS), control of livestock movement for bio-security management, meat inspection in abattoirs and advice on necessary livestock inputs (Lo Moro, Chatterji, Hatzipetros, Ghamie \& Tsopito, 2014:30). However, extension services in Botswana's agriculture sector have been criticised for inefficiency and stagnation over the last ten years (Engelen, Malope, Keyser \& Neven, 2013:102). The inefficiency of extension services would have led to a skills gap among farmers and thus the need to analyse the needs in order to improve the competence and stress the need for the revitalisation of extension services. The main objective of this study was to conduct the training needs assessment among smallholder livestock owners in selected areas in order to profile and identify their critical training needs in livestock production.

\section{METHODOLOGY}

The study was carried out in Botswana. Botswana is located on latitude $24^{\circ} 45 \mathrm{~S}$ and longitude $25^{\circ} 55 \mathrm{E}$ with a land area of 582,000 squares kilometers at the south of the Equator and dissected by the Tropic of Capricorn. Botswana is in both the eastern and southern hemispheres and is a landlocked country positioned in southern Africa. It is bordered by South Africa to the south and Southeast, Namibia to the west, Zambia to the north and Zimbabwe to the northeast. The economy is closely tied to South Africa's, and is dominated by mining (especially diamonds), tourism, cattle, dry land farming and irrigated crop production.

This Training Needs Assessment Survey (TNAS) covered the South East and Central Districts of Botswana. In the South East District, Mogobane, Boatle and Taung villages were covered, while in the Central District, Bobonong, Letlhakane, Nata and Serowe villages were covered by the survey. Table 1 below shows the areas covered and the percentage ratio of respondents who were interviewed. These were part of the areas where previous smallholder livestock competitiveness studies were carried out. A random sampling technique was used to select livestock farmers for formal interview in the each of the areas.

Table 1: Location and percentage distribution of respondents

\begin{tabular}{|l|c|c|}
\hline \multicolumn{1}{|c|}{ Location } & Frequency (N) & Percentage \\
\hline $\begin{array}{l}\text { South East (Mogobane, Boatle \& } \\
\text { Taung) }\end{array}$ & 54 & 13.7 \\
\hline Serowe & 96 & 24.3 \\
\hline Nata & 85 & 21.5 \\
\hline Letlhakane & 74 & 18.7 \\
\hline Bobonong & 86 & 21.8 \\
\hline TOTAL & $\mathbf{3 9 5}$ & $\mathbf{1 0 0}$ \\
\hline
\end{tabular}

Two approaches were used to collect data: individual interview using a standard questionnaire and a focus group discussion. A quantitative data collection instrument (questionnaire) was designed to measure the perceived level of knowledge and skill on a list of topics related to livestock production. The topics followed a logical sequence of production chain. 
S. Afr. J. Agric. Ext.

Vol. 46, No. 1, 2018: 92 - 105

DOI: http://dx.doi.org/10.17159/2413-3221/2018/v46n1a450

The second approach was a focus group discussion in each of the areas. During the administration of the questionnaire, the respondents and other farmers were invited to the focus group discussion sessions where the facilitator motivated the participants to come up with current status of their farming and the practices which need to be introduced in order to improve livestock system in their areas.

A Likert scale was used to measure the level of knowledge and skills that respondents perceived to possess about the topics in the questionnaire. The perceived knowledge and skills are competencies that are inculcated through teaching and learning process. Training is a product of teaching and learning and follows the three domains of learning which are the cognitive, psychomotor and the affective domains. Knowledge is a component of cognitive domain because it is considered abstract in its form, while the psychomotor domain is characterised by physical, manual or manipulative skills (Kennedy, 2006:38). The Likert scale uses fixed choice response formats to measure attitudes and opinions of respondents. The scale is designed to measure the competencies and attempts to "measure what an individual believes, perceives, or feels about self, others, activities, institutions or situations" (Gay, Mills \& Airasian, 2009:150).

The results presented in this document are from the quantitative data which used a Likert scale to measure the perceived level of knowledge and skill. A four-point Likert scale was used. A scale of 1 represented Very Knowledgeable and the extreme scale of 4 represented Not Knowledgeable. The same Likert scale measure was used to represent the perceived level of skill. The means and standard deviations were used to indicate the level of knowledge and skill respectively the respondent indicated against the statement. Therefore, means between 1 and 2.49 indicate possession of knowledge or skill respectively, while the means from 2.5 to 4 indicate ambiguity on knowledge and skill to complete lack of knowledge and skill respectively about the statement.

\section{RESULTS AND DISCUSSION}

\subsection{Demographic characteristics}

Table 2 discusses the demographic characteristics of respondents. The majority of those interviewed were male (57\%) compared to females who were at $43 \%$. Regarding their educational level, $18 \%$ had never been to school; $34 \%$ had attained primary school level education; $33 \%$ had gone through secondary school and $15 \%$ had gone as far as tertiary level. 
S. Afr. J. Agric. Ext.

Vol. 46, No. 1, 2018: 92 - 105

DOI: http://dx.doi.org/10.17159/2413-3221/2018/v46n1a450
Tselaesele, Bagwasi, Lepetu,

Bahta \& Oladele.

(License: CC BY 4.0)

Table 2: Demographic characteristics of respondents

\begin{tabular}{|l|c|c|}
\hline Variables & Frequency (N) & Percentage \\
\hline Gender & & 57 \\
\hline Male & 225 & 43 \\
\hline Female & 170 & $\mathbf{1 0 0}$ \\
\hline Total & $\mathbf{3 9 5}$ & 18 \\
\hline Level of Education & & 34 \\
\hline Never been to school & 71 & 33 \\
\hline Primary school & 134 & 15 \\
\hline Secondary school & 130 & $\mathbf{1 0 0}$ \\
\hline Tertiary & 59 & \\
\hline Total & $\mathbf{3 9 4} *$ & \\
\hline
\end{tabular}

*One respondent did not state his level of education

\subsection{Perceived Knowledge and Skill on Animal Breeding}

Table 3 presents results regarding the perceived level of knowledge and skill related to animal breeding. Results show that respondents are knowledgeable in three areas. These are: characteristics of the best bull needed for breeding (mean $=2.3$ and $\mathrm{SD}=1.0$ ); identify cows with ideal characteristics for breeding (Mean $=2.43$ and $\mathrm{SD}=.98$ ) and Determine when the cow is on heat (Mean $=2.35$ and SD =1.0). All other statements fall within the category of somewhat knowledgeable to not knowledgeable. Respondents were somewhat knowledgeable and somewhat skilled in the following: use of artificial insemination, management of pregnant cows, identifying recommended breeds of cattle, calculation of calving percentage and calculation of mortality rate. These items are important in improvement of livestock and the results indicate that livestock farmers are not knowledgeable and skilled to practise them. The overall mean for all the statements is 2.58 and a $\mathrm{SD}=.99$. Thus generally, respondents are not knowledgeable about topics related to breeding. This is similar to the results from a study by Banda \& Kazembe, (2008) where respondents perceived that they needed training on breeds and breeding.

With regard to skill level perceived by respondents, the results show that all the statements fall on the category of somewhat skilled to not skilled. The use of artificial insemination (Mean 3.58., SD =.8) is very important to the communal livestock farmers for improving their breeds. However, they reported during the focus group discussion that these facilities are too far away from their cattle posts to access them. Beside the distance, they reported that the semen containers and liquid nitrogen which is used for preserving semen are very expensive to purchase and maintain. 
S. Afr. J. Agric. Ext.

Vol. 46, No. 1, 2018: 92 - 105

DOI: http://dx.doi.org/10.17159/2413-3221/2018/v46n1a450
Tselaesele, Bagwasi, Lepetu,

Bahta \& Oladele.

(License: CC BY 4.0)

Table 3: Statement about livestock breeding

\begin{tabular}{|c|c|c|c|c|}
\hline Statement about livestock breeding & \multicolumn{2}{|c|}{ Knowledge } & \multicolumn{2}{|c|}{ Skill } \\
\hline & Mean & SD & Mean & SD \\
\hline Identify characteristics of the best bull needed for breeding & 2.37 & 1.0 & 2.62 & 1.0 \\
\hline Identify cows with ideal characteristics for breeding & 2.43 & .98 & 2.68 & .97 \\
\hline Determine when the cow is on heat & 2.35 & 1.0 & 2.59 & 1.1 \\
\hline Use Artificial Insemination technique & 2.68 & 1.0 & 3.58 & .80 \\
\hline Management of pregnant cows & 2.59 & 1.0 & 2.81 & 1.0 \\
\hline Identify the recommended breeds of cattle & 2.53 & .99 & 2.72 & .99 \\
\hline Calculate calving percentage & 2.91 & .96 & 3.06 & .94 \\
\hline Calculate mortality rate & 2.77 & .98 & 2.88 & .97 \\
\hline TOTAL & 2.58 & & 2.87 & \\
\hline \multicolumn{5}{|c|}{$\begin{array}{l}\text { 1=Very Knowledgeable } \quad 2=\text { Knowledgeable } 3=\text { Somewhat Knowledgeable } 4=\text { Not } \\
\text { Knowledgeable }\end{array}$} \\
\hline $\begin{array}{l}1=\text { Very Skilled } \\
\text { Skilled }\end{array}$ & lled & & 4 & Not \\
\hline
\end{tabular}

\subsection{Knowledge and Skill on Range Management}

Table 4 contains the results of assessing the knowledge and skill about range management. Regarding the perceived knowledge level, results show that respondents are knowledgeable about the following: Identify overgrazing (Mean $=1.87, \mathrm{SD}=.81$ ), ability to identify causes of overgrazing (Mean $=2.03, \mathrm{SD}=.84$ ), identify that there is soil erosion in the area (Mean $=1.98, \mathrm{SD}=.96)$, distinguish different types of soil erosion $($ Mean $=2.45, \mathrm{SD}=1.1$ ), determine causes of soil erosion (Mean $=2.2, \mathrm{SD}=.95$ ) and distinguish types of grasses (Mean $=2.47, \mathrm{SD}=.93$ ). The range management aspects which respondents did not have a good knowledge and skill level of were stocking rate of the range with Knowledge level (Mean $=3.01, \mathrm{SD}=1.0)$ and Skill level (Mean = 3.40. SD =.79). In addition, knowledge and skill on rotational grazing of pasture has Knowledge level (Mean $=2.72, \mathrm{SD}=1.1$ ) and Skill (Mean $=3.06, \mathrm{SD}=.95)$ and range assessment techniques with Knowledge (Mean $=2.82$, $\mathrm{SD}=1.1$ ) and Skill (Mean $=2.97, \mathrm{SD}=.97$ ). The overall mean for this category of knowledge is $($ Mean $=2.46)$ indicating that the respondents are somewhat knowledgeable about topics related to range management.

As for perceived level of skill on the same topics, respondents perceive to have skill on the following three topics: identify over grazing (Mean $=1.98, \mathrm{SD}=.86$ ), ability to determine the causes of overgrazing (Mean $=2.10 ; \mathrm{SD}=.86$ ), identify that there is soil erosion in our area (Mean $=2.20 ; \mathrm{SD}=.96)$. The overall mean of 2.61 and SD $=.94$, indicates that the respondents were somewhat skilled about the topics related to range management. The study conducted by Lioutas, Tzimitra-Kalogianni \& Charatsari, (2010:5) identified among others the management of pasture as areas that respondents were indifferent about, as such indicating the need to train them on. 
S. Afr. J. Agric. Ext.

Vol. 46, No. 1, 2018: 92 - 105

DOI: http://dx.doi.org/10.17159/2413-3221/2018/v46n1a450
Tselaesele, Bagwasi, Lepetu,

Bahta \& Oladele.

(License: CC BY 4.0)

Table 4: Statements about range management

\begin{tabular}{|c|c|c|c|c|}
\hline \multirow[t]{2}{*}{ Statements about Range Management } & \multicolumn{2}{|c|}{ Knowledge } & \multicolumn{2}{|c|}{ Skill } \\
\hline & Mean & SD & Mean & SD \\
\hline Identify over grazing & 1.87 & .81 & 1.98 & .86 \\
\hline Ability to determine the causes of overgrazing & 2.03 & .84 & 2.10 & .86 \\
\hline Identify that there is soil erosion in our area & 1.98 & .96 & 2.06 & .99 \\
\hline Distinguish different types of soil erosion & 2.45 & 1.1 & 2.56 & 1.1 \\
\hline Determine causes of soil erosion & 2.20 & .95 & 2.20 & .96 \\
\hline Identify bush encroachment in the grazing area & 2.80 & .92 & 2.93 & .95 \\
\hline Distinguish types of grasses & 2.47 & .93 & 2.60 & .95 \\
\hline Distinguish quality of grasses that are suitable for grazing & 2.53 & .98 & 2.66 & 1.0 \\
\hline Identify invasive plants & 2.52 & .92 & 2.63 & .92 \\
\hline Identify poisonous plants & 2.54 & .94 & 2.75 & .94 \\
\hline Stocking rate of the range & 3.01 & 1.0 & 3.40 & .79 \\
\hline Rotational grazing of the pasture & 2.72 & 1.1 & 3.06 & .95 \\
\hline Range assessment techniques & 2.82 & 1.1 & 2.97 & .97 \\
\hline TOTAL & 2.46 & & 2.61 & \\
\hline \multicolumn{5}{|c|}{$\begin{array}{l}1=\text { Very Knowledgeable } \quad 2=\text { Knowledgeable: } 3=\text { Somewhat Knowledgeable } 4=\text { Not } \\
\text { Knowledgeable }\end{array}$} \\
\hline $\begin{array}{l}1=\text { Very Skilled } \\
\text { Skilled }\end{array}$ & illed & & 4 & Not \\
\hline
\end{tabular}

\subsection{Knowledge and skill on Feeds and Feeding}

Feeding livestock good quality feeds is one of the practices that can result in animals withstanding drought and poor range conditions. Table 5 indicates the rating which respondents gave regarding their perceived level of knowledge about livestock feeds and feeding. The results show that respondents are only knowledgeable about supplementing livestock (Mean $=2.27, \mathrm{SD}=.99$ ). Otherwise they perceive themselves to have some knowledge about livestock feeds and feeding.

With regard to the perceived level of skill, respondents indicated that they were somewhat knowledgeable about the perceived level of skill regarding feeds and feeding. Botswana has been known to be a drought-prone country even before the concerns of climate change became pronounced. It has since become imperative for extension workers in animal production to advice livestock farmers to adopt some technologies which are critical to the survival of their livestock during dry period. It is critical that livestock farmers are trained in some of the technologies listed below. 
S. Afr. J. Agric. Ext.

Vol. 46, No. 1, 2018: 92 - 105

DOI: http://dx.doi.org/10.17159/2413-3221/2018/v46n1a450
Tselaesele, Bagwasi, Lepetu,

Bahta \& Oladele.

(License: CC BY 4.0)

Table 5: Statements about feeds and feeding

\begin{tabular}{|c|c|c|c|c|}
\hline \multirow[t]{2}{*}{ Statements about Feeds and Feeding } & & Knowledge & \multicolumn{2}{|c|}{ Skill } \\
\hline & Mean & SD & Mean & SD \\
\hline Supplement livestock & 2.27 & .99 & 2.63 & .99 \\
\hline Prepare silage & 3.20 & .95 & 3.47 & .84 \\
\hline Prepare urea molasses block & 3.15 & .99 & 3.40 & .91 \\
\hline Grow suitable fodder crops & 2.77 & 1.1 & 3.11 & .98 \\
\hline To safely store fodder & 2.67 & 1.0 & 2.91 & $\mathbf{1 . 0}$ \\
\hline Determine the water quality for livestock & 2.81 & 1.1 & 3.03 & 1.0 \\
\hline TOTAL & 2.8 & & 3.09 & \\
\hline \multicolumn{5}{|c|}{$\begin{array}{l}\text { I=Very Knowledgeable } \quad 2=\text { Knowledgeable: } 3=\text { Somewhat Knowledgeable } 4=\text { Not } \\
\text { Knowledgeable }\end{array}$} \\
\hline $\begin{array}{l}1=\text { Very Skilled } \\
\text { Skilled }\end{array}$ & $3=$ Somewhat Skilled & & & $=N o t$ \\
\hline
\end{tabular}

\subsection{Knowledge and Skill on Livestock Management Practices}

Livestock management practices are activities that are conducted regularly on livestock to improve their quality and safeguard them from diseases and other conditions. Table 6 contains statements about practices which are regularly done in livestock management. With regard to perceived level of knowledge of these practices, respondents indicated that they were knowledgeable about all of them. However, respondents were skilled or somewhat skilled on most of the statements except on "weighing" which was had a mean $=3.60, \mathrm{SD}=$ .76 , therefore falling within the range of somewhat skilled.

Table 6: Statements about livestock management practices

\begin{tabular}{|l|l|l|l|l|}
\hline Statements about Livestock Management Practices & Knowledge & \multicolumn{2}{|c|}{ Skill } \\
\hline & Mean & SD & Mean & SD \\
\hline Dehorning & 1.88 & .95 & 2.23 & 1.1 \\
\hline How to use a syringe to vaccinate & 1.86 & .86 & 2.28 & 1.1 \\
\hline Use a burdizzo to castrate & 1.80 & .85 & 2.10 & 1.1 \\
\hline Use a rubber ring elastrator & 1.89 & .94 & 2.20 & 1.2 \\
\hline Ear tag livestock & 2.10 & .98 & 2.67 & 1.1 \\
\hline Hoof trimming & 2.10 & 1.0 & 2.46 & 1.2 \\
\hline Branding cattle & 1.75 & .98 & 1.97 & 1.1 \\
\hline Dipping livestock to control ticks & 1.73 & .89 & 1.94 & 1.1 \\
\hline Wound dressing & 2.10 & .98 & 2.36 & 1.0 \\
\hline Control eye infection in Livestock & 2.41 & .94 & 2.65 & 1.0 \\
\hline Identify the symptoms of livestock diseases & 2.38 & .94 & 2.70 & .95 \\
\hline Dosing for internal parasites & 2.36 & 1.0 & 2.64 & 1.1 \\
\hline Weighing & 3.13 & 1.0 & 3.60 & .76 \\
\hline TOTAL & $\mathbf{2 . 1 1}$ & & $\mathbf{2 . 4 5}$ & \\
\hline
\end{tabular}

$1=$ Very Knowledgeable $\quad 2=$ Knowledgeable: $3=$ Somewhat Knowledgeable $4=$ Not Knowledgeable 
S. Afr. J. Agric. Ext.

Vol. 46, No. 1, 2018: 92 - 105

DOI: http://dx.doi.org/10.17159/2413-3221/2018/v46n1a450

$1=$ Very Skilled

Skilled
Tselaesele, Bagwasi, Lepetu,

Bahta \& Oladele.

(License: CC BY 4.0)

\subsection{Knowledge and Skill on Farm Records and Accounts}

The performance of any farm enterprise is influenced by many factors which include, the technology adopted on the farm, the prices of inputs, climatic conditions and institutions that operate within an agricultural system. It is important that farm records be kept in order for farm owners/managers to be able to monitor and evaluate the performance of their production and make well informed decisions about their farm enterprises. Table 7 contains data on the perceived knowledge and skill levels of livestock farmers about farm record. The results show that respondents are somewhat knowledgeable and not knowledgeable. During focus group discussions, participants confirmed that they were not keeping records at all. The results from focus group discussion confirmed that the farmers did not keep farm records. The reason given was that they got very demoralised when they observed in their records that their farm enterprises were not doing well.

Respondents indicated that they were not skilled about any of the farm records listed. During focus group discussions, the respondents indicated that though they may know why farm records are kept, they did not have the expertise to keep them properly. Farm records and accounts as well as financial management featured prominently in the following studies, (Banda \& Kazembe, 2008:14; Vigne \& Motinga, 2005:22). This is an indication of a serious problem in farm management if farmers cannot keep proper records of their enterprises.

Table 7: Statements about farm records and accounts

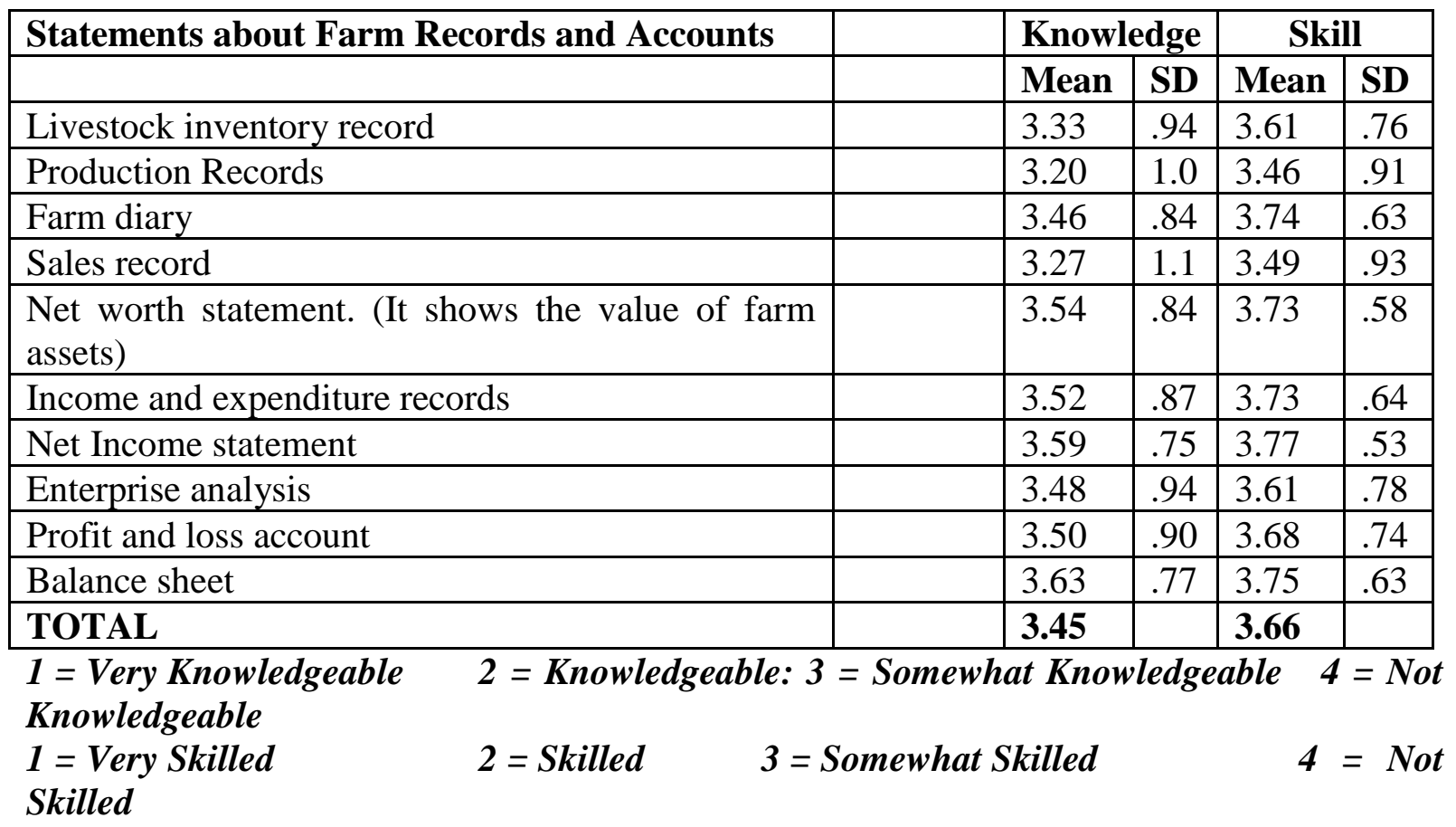

\subsection{Knowledge and Skill about Livestock Facilities}

Livestock facilities listed in Table 8 are regarded as important for the handling and providing safety to farm animals. According to knowledge levels, respondents were knowledgeable 
S. Afr. J. Agric. Ext.

Vol. 46, No. 1, 2018: 92 - 105

DOI: http://dx.doi.org/10.17159/2413-3221/2018/v46n1a450

about these facilities and technologies except for borehole maintenance (Mean=3.00, SD = 1.1). On the other hand, respondents were somewhat skilled on the following: crush construction $($ Mean $=2.79, \mathrm{SD}=1.2)$, borehole construction $($ Mean $=3.24, \mathrm{SD}=1.0$ ) and water harvesting technologies $(\mathrm{Mean}=2.48, \mathrm{SD}=1.0$ ). It is understandable that respondents may not be skilled on crush construction because their construction in communal areas is done by the Ministry of Agriculture employees who have to follow certain established standards of crush construction. Similarly, the borehole maintenance is usually done by specialised artisans who have gone through formal training in the area of mechanical engineering.

Table 8: Statements about livestock facilities

\begin{tabular}{|l|l|l|l|l|}
\hline Statements about Livestock Facilities & Knowledge & \multicolumn{3}{|c|}{ Skill } \\
\hline & Mean & SD & Mean & SD \\
\hline Crush construction & 2.40 & 1.1 & 2.79 & 1.2 \\
\hline Borehole maintenance & 3.00 & 1.1 & 3.24 & 1.0 \\
\hline Fence Construction and maintenance & 2.17 & 1.1 & 2.41 & 1.1 \\
\hline Water harvesting technologies & 2.32 & 1.0 & 2.48 & 1.0 \\
\hline TOTAL & $\mathbf{2 . 4 7}$ & & $\mathbf{2 . 7 3}$ & \\
\hline
\end{tabular}

$1=$ Very Knowledgeable $\quad 2$ = Knowledgeable: 3 = Somewhat Knowledgeable $4=$ Not Knowledgeable

$1=$ Very Skilled

$2=$ Skilled $\quad 3=$ Somewhat Skilled

$4=$ Not Skilled

\subsection{Perceived Topics of Interest in Livestock Training}

Table 9 contains the technical animal health and production topics which respondents identified as their gap in their knowledge that respondents wished to receive training on. Some of these technical livestock production areas were not covered in other tables because they are somewhat highly specialised and have been hitherto undertaken by staff of the departments of the Ministry of Agriculture such as the Department of Veterinary Services (DVS). Some five years back, the Veterinary Department discontinued these services and farmers have been left without any systematic up skilling. This reasoning was also expressed during focus group discussions. 
S. Afr. J. Agric. Ext.

Vol. 46, No. 1, 2018: 92 - 105

DOI: http://dx.doi.org/10.17159/2413-3221/2018/v46n1a450
Tselaesele, Bagwasi, Lepetu,

Bahta \& Oladele.

(License: CC BY 4.0)

Table 9: Perceived level of interest in livestock topics that respondents prefer to be trained on

\begin{tabular}{|l|l|l|}
\hline Statements about Area of Training & \multicolumn{2}{|l|}{$\begin{array}{l}\text { Level of Need } \\
\text { for training }\end{array}$} \\
\hline & Mean & SD \\
\hline Infectious diseases (e.g. FMD, heart water, brucellosis etc) & 2.67 & .59 \\
\hline Parasitic diseases (internal and external parasites) & 2.61 & .61 \\
\hline Nutritional diseases (e.g. bloat, rickets etc) & 2.63 & .59 \\
\hline Livestock feeds and feeding & 2.47 & .71 \\
\hline Farm records and accounts & 2.30 & .78 \\
\hline Animal breeding and reproduction & 2.56 & .69 \\
\hline Livestock marketing & 2.29 & .82 \\
\hline Range management & 2.03 & .81 \\
\hline Livestock handling facilities & 1.80 & .78 \\
\hline Borehole maintenance & 2.10 & .83 \\
\hline Agricultural Credit & 2.26 & .81 \\
\hline Hides and skin management and processing & 2.27 & .86 \\
\hline Average & $\mathbf{2 . 3 3}$ & \\
\hline
\end{tabular}

$1=$ Do not need Training on the subject area, $2=$ would need Training on the subject area and $3=$ strongly need training on the subject area

\section{CONCLUSIONS AND RECOMMENDATIONS}

Because majority of livestock in Botswana are found in communal areas and owned by a sizeable number of smallholder farmers who do not regularly sell their livestock, high stock losses are experienced. This study has shown that livestock farmers in communal areas are not well exposed to some technical knowledge and skill which they can use to improve their production and management practices. Respondents were knowledgeable and skilled on livestock management practices. These are routine practices in livestock systems in Botswana. Respondents were somewhat knowledgeable and somewhat skilled in animal breeding activities. In addition, respondents were not knowledgeable and not skilled in the area of farm records and accounts. The results show that practical skills should be the major component of any livestock farmer training so as to enhance livestock production among smallholder livestock farmers.

It is recommended that livestock extension workers put emphasis on training smallholder livestock farmer's aspects of farm records and accounts as well as breeding. It is further recommended that farmer training institutions in the country complement livestock extension training efforts by design training programmes that address areas that this study has identified as contributing to low productivity within smallholder livestock farmers.

\section{REFERENCES}

ALIBAYGI, A. \& ZARAFSHANI, K. 2008. Training Needs of Iranian Extension Agents about Sustainability: The Use of Borich's Need Assessment Model. Afr. J. Agric. Res., 3(10):618-687. 
DOI: http://dx.doi.org/10.17159/2413-3221/2018/v46n1a450 (License: CC BY 4.0)

BAHTA, S., BAKER, D., PODISI., B. \& MAROBELA, O. 2013. Competitive Smallholder Livestock in Botswana: Results of a livestock value chain survey in the Central district of Botswana. International Livestock Research Institute, Nairobi.

BAHTA S. \& MALOPE, P. 2014. Measurement of competitiveness in smallholder livestock systems and emerging policy advocacy an application to Botswana. Food Policy., 49:408-417. http://dx.doi.org/10.1016/j.foodpol.2014.10.006.

BAHTA, S., \& BAKER, D. 2015. Determinants of Profit Efficiency among Smallholder Beef Producers in Botswana. IFAMR., 18(3):107-120.

BAHTA, S., BAKER, D., MALOPE, P. \& KATJIUONGUA, H. 2015. A Meta-frontier Analysis of Determinants of Technical Efficiency in the Beef Farm Types: An Application to Botswana. Paper Presented at International Conference of Agricultural Economists, Milan, Italy from August 8th-14th August 2015.

BANDA, J. W. \& KAZEMBE, J. A. 2008. Livestock Sector Training Needs Assessment Report for Southern Africa, International Livestock Research Institute, Nairobi.

CEKADA, T. L. 2010. Training Needs Assessment: Understanding what Employees Need to Know. Professional Safety, www.asse.org. Viewed February 2016.

CULLIS, A. \& Watson, C. 2005. Winners and Losers: Privatising the Commons in Botswana. International Institute for Environment and Development. WillPrint, Colchester.

ENGELEN, A., MALOPE, P., KEYSER, J. \& NEVEN, D. 2013. Botswana Agrifood Value Chain Project-Beef Value Chain Study. Food and Agriculture Organization and Ministry of Agriculture. Rome.

FERREIRA, R. R. \& ABBAD, G. 2012. Training Needs Assessment: Where We Are and Where We Should Go. BAR, Rio de Janeiro., 10(1):77-99.

GAY, L. R., MILLES, E. G. \& AIRASIAN, P. 2009. Educational Research: Competencies for Analysis and Applications (9th Edition), Pearson Educational Inc. Upper Saddle River.

HENDRICKX, K. \& MBEHA, A. 2013. Findings of Participatory Epidemiology Fieldwork, ILRI. (Unpublished report).

JEFFERIS, K. 2007. Impact of Cattle/Beef Prices on Incomes and Poverty in Botswana, in file:///H:/ILRI\%20CICE\%20Poject/The\%20Impact\%20of\%20Cattle\%20Beef\%20Pric es\%20n\%20Poverty.pdf Viewed 22.05.2016.

KENNEDY, D. 2006. Writing and using learning outcomes: a practical guide, Watermans Printers, Cork University College, Cork.

LIOUTAS, E. D. TZIMITRA-KALOGIANNI, I. \& CHARATSARI, C. 2010. Small Ruminant Producer's Training Needs and Factors Discouraging Participation in Agricultural Education/Training Programs. Livest. Res. Rural Dev., 22(7):1-7.

LO MORO, P., CHATTERJI, S., HATZIPETROS, A., GHANIE, S. \& TSOPITO, C. 2014. Private Sector Development Programme Botswana (PSDP) -Beef Value Chain Findings, Strategy and Proposed Interventions, International Trade Centre.

MAHABILE, M. 2006. Determinants of Herd Productivity in Botswana: A Focus on Land Tenure and Land Policy, PhD Thesis. University of KwaZulu-Natal.

MAHABILE, M., LYNE, M. C. \& PANIN, A. 2005. An empirical Analysis of Factors Affecting the Productivity of Livestock in Southern Botswana. Agrekon., 44(1):99117.

MINISTRY OF AGRICULTURE, 2010. Livestock Management and Infrastructure Development (LIMID) Phase II - Implementation Guidelines, Department of Animal Production, Gaborone. 
S. Afr. J. Agric. Ext.

Vol. 46, No. 1, 2018: 92 - 105

DOI: http://dx.doi.org/10.17159/2413-3221/2018/v46n1a450

MMOPELWA, D. \& SELEKA, T. B. 2011. Factors Underlying Communal Beef Cattle Marketing Decisions in Botswana: The Role of Public and Private Transfers. Botswana Institute for Development Policy Analysis Working Paper No: 30.

NISCHITHAA, P. \& RAO NARASIMHA, M. V. A. L. 2014. The Importance of Training and Development Programmes in the Hotel Industry. IJBARR 1 (5) 2014 50-56. EISSN No. 2347 -685X, ISSN $2348-0653$.

NKHORI, P. A. 2004. The Impact of Transaction Costs on the Choice of Markets in Mahalapye District. MSc Dissertation, University of Pretoria.

OLADELE, O. I., LEPETU, J., SUBAIR, S. K., \& OBUH, J. 2009. SWOT Analysis of Extension Systems in Southern African Countries. JAEID., 103(4):309-320.

SKILLNETS. 2013. Training Needs Analysis Guide, Training Networks Programme, Dublin. http://www.skillnets.ie/ viewed February 2016.

STATISTICS BOTSWANA. 2014. 2012 Annual Agricultural Survey Report, Department of Printing and Publishing Services, Gaborone.

UNIVERSITY OF VICTORIA. Undated. What Makes Up Competency? Co-operative Education Program and Career Services. www.uvic.ca/coopandcareer. Viewed February 2016.

VIGNE, P. \& MOTINGA, D. 2005. Assessing Training Needs Among AALS Farmers: Cash and Skills Needed to Farm Successfully in Namibia. IPPR Research Report 7.

WINTERTON, J., LE DEIST, F.D. \& STRINGFELLOW, E. 2005. The Typology of Knowledge, Skills and Competencies: Clarification of the Concepts and Prototypes. European Centre for the Development of Vocational Training, Italy. 